原 著

\title{
後頭部焦点を示すてんかんの臨床・脳波学的研究
}

\section{Clinico-electroencephalographical Study of Epilepsy with Occipital Seizure Discharges}

$$
\begin{array}{lllllr}
\text { 斎 藤 } & \text { 文 } & \text { 男 }^{*} & \text { 福 } & \text { 島 } & \text { 裕 } \\
\text { 久保田 } & \text { 修 } & \text { 司 } & \text { 佐 } & \text { 藤 } & \text { 時治郎 }
\end{array}
$$

\begin{abstract}
要旨: 後頭部発作波を示すてんかん 27 症例を臨床・脳波学的に検討した。後頭部発作波は 8〜11歳で最も出現しやすかった。発作は視覚症状の及ならず, 焦点運動発作, 複雑部分発 作, 全身痤攣発作など多様な症状を示した。発作波の睡眠, 開閉眼に対する反応性は一様 でなかった。発作の予後は必ずしも良くなかった。予後を左右するのは，脳波パターンよ り 子発症年齢, 器質性脳障害, 知能障害, 複䧴部分発作などの因子であると考光られた。

Gastaut の提唱した benign partial epilepsy of childhood with occipital spike-wave (BEOSW) をめぐって考察を加 光, 後頭部反復律動性棘徐波が特異な臨床・脳波学的一 単位の指標とは考壳がたいことを述べた。
\end{abstract}

てんかん研究 $1985 ; 3: 108-116$

Key Words: epilepsy, occipital seizure discharge, prognosis, change of EEG focus, benign partial epilepsy.

\section{はじめに}

後頭部に発作波焦点を有するてんかんは，その 出現率が比較的低いこともあって，今だに臨床・ 脳波学的検討が十分加兄られているとは言いがた い。とくに，その経過・予後に関する報告は少な い。最近 Gastaut ${ }^{5)}$ は, すでによく知られている benign epilepsy of children with centrotemporal EEG foci (以下 BECCT) に匹敵する予後良好な 部分てんかんとして，後頭部に棘徐波複合を示す 一群 benign partial epilepsy of childhood with occipital spike-waves (以下 BEOSW) の存在を提 唱しているが，まだ BECCT ほどに一定の評価 を得ているとはいえない。
今回，著者らは，後頭部発作波を示すてんかん の臨床像，脳波所見ならびそ経過について総合的 に検討したので報告する。

\section{I. 対 象}

対象は1972年 1 月から1981年12月までの10年間 に弘前大学神経精神科外来を受診し，てんかんと 診断された症例のらち，発作間歇時脳波で後頭部 発作波焦点を示したものを選択した。症例の中に は，第 2 回目以降の記録で初めて発作波の出現を みた例も含めた。発作波には棘波，鋭波，棘徐波 複合，鋭徐波複合をとりあげ，14\&6 陽性棘波， $6 \mathrm{~Hz}$ ファントム梀徐波複合は除外した (Fig. 1)。

\footnotetext{
* 弘前大学医学部神経精神医学教室 [于036 弘前市在府町 5]

Fumio Saito, Yutaka Fukushima, Shuji Kubota, Tokijiro Sato

Department of Neuropsychiatry, Hirosaki University School of Medicine, Hirosaki

1985年 7 月 16 日受理
} 


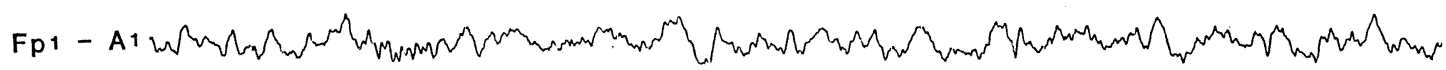

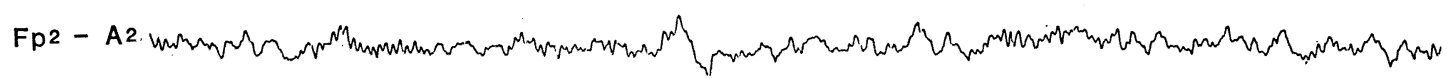

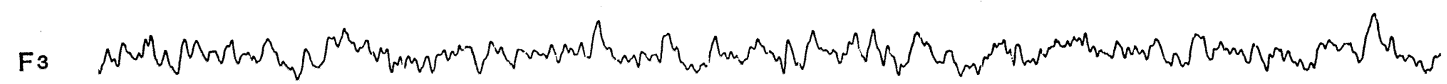

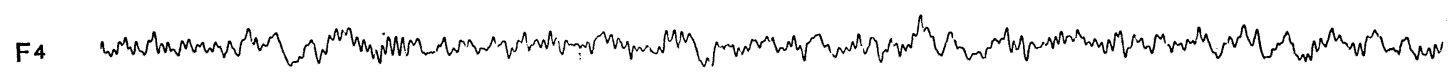

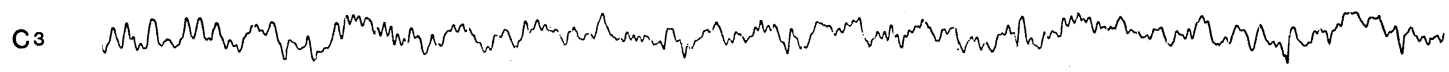

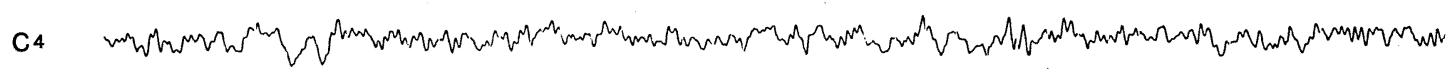

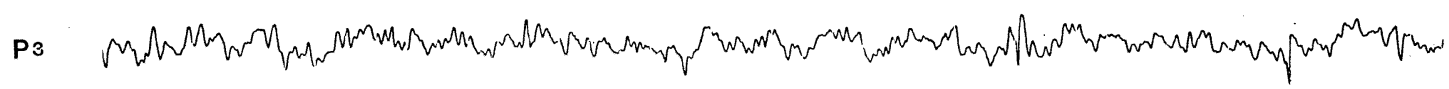

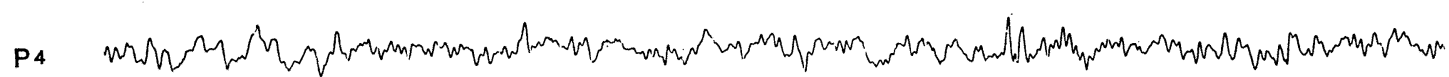

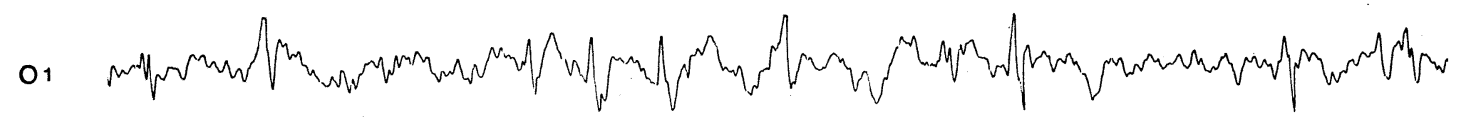

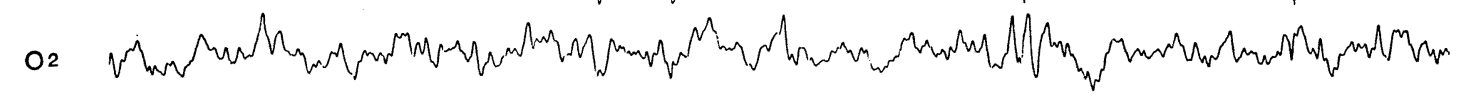

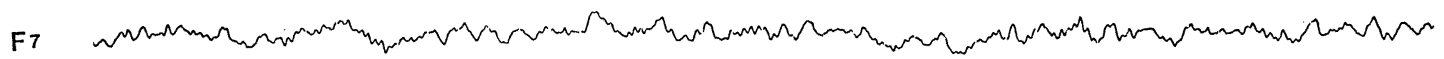
F 8

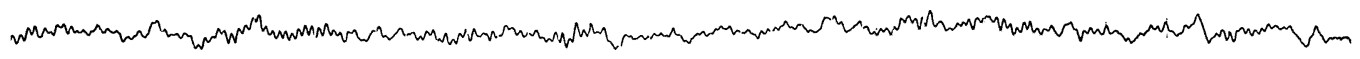

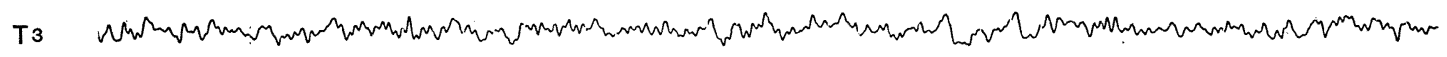

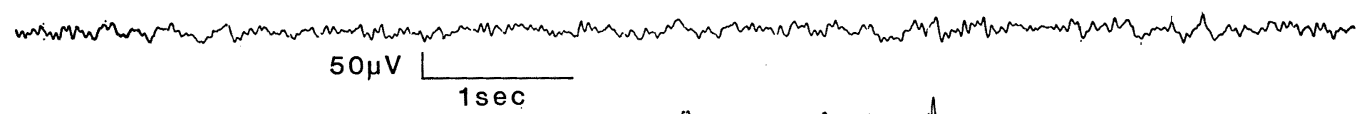
T5

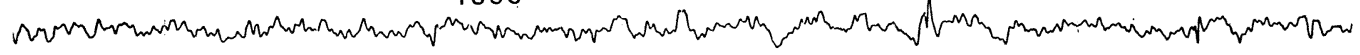

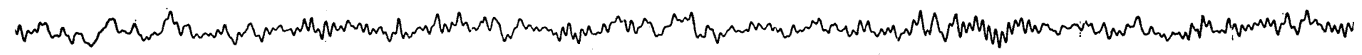

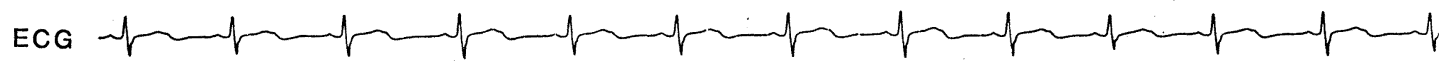

Fig. 16 year old male with focal motor seizures

Occipital spikes predominant on the left side.

\section{II. 結 果}

\section{1. 年齢分布}

上記の基準をみたすてんかん患者は 27 例であ り，10年間に受診したてんかん患者総数（916例） の $2.9 \%$ にあたる。このうち，男性は 11 例（40 $\%)$ ，女性は 16 例 $(59 \%)$ であった。母集団の年
龄構成を初診時年齢でみると Fig. 2 のような分 布をとった。後頭部発作波を示す例は小児期の広 い年齢層にみられたが，とくに8～11歳の年蹂群 で有意に高い出現率を示した。てんかん発作の初 発は 8 １1歳にピークを認めるが，症例の $1 / 3$ は 3 歳以前の発症であった (Fig. 3-A)。一方, 発 作波の初出年齢は $8 \sim 11$ 歳にピークを有する一峰 


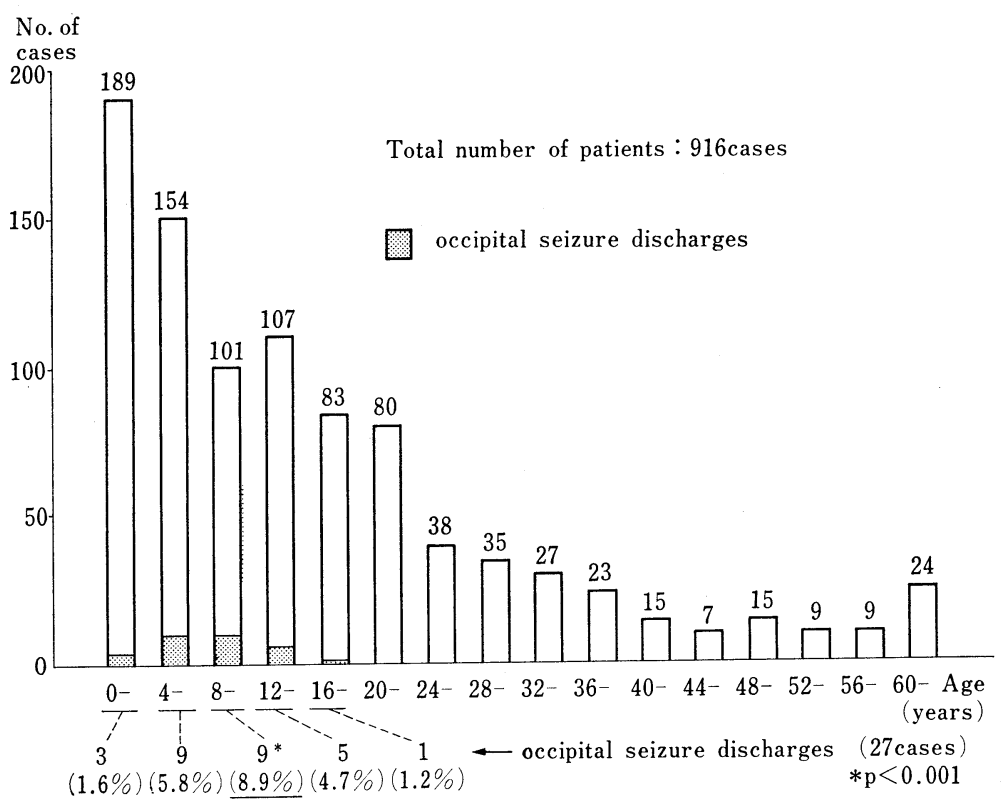

Fig. 2 Age distribution of the patients with epilepsy and incidence of occipital seizure discharges
(A) Clinical Seizure $4 \mathrm{M} \sim 14 \mathrm{Y} 4 \mathrm{M}$ (mean 6Y5M)

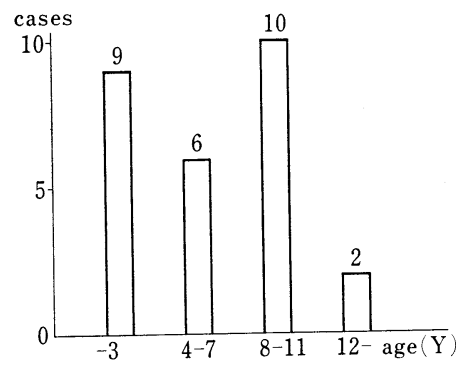

(B) Occipital Seizure Discharges $1 \mathrm{Y} 8 \mathrm{M} \sim 17 \mathrm{Y} 4 \mathrm{M}$ (mean 8Y7M)

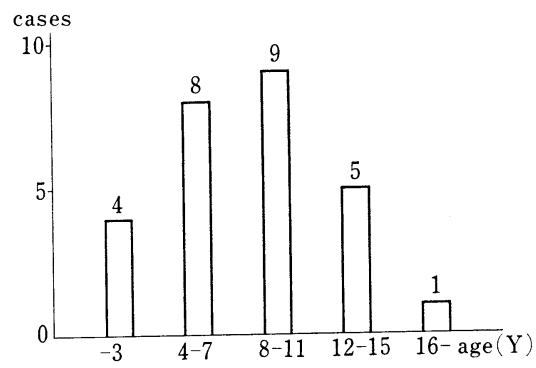

Fig. 3 Age when the first seizure occurred (A) and when occipital seizure discharge was first discovered (B)

性の分布を示した (Fig. 3-B)。

\section{2. 臨床発作の特徵}

27 例の発作型を分類すると，単純部分発作14例 (52\%), 複雑部分発作（意識障害で開始するも の） 5 例 $(19 \%)$, 焦点症状の不明確な 全身痤攣 発作 8 例 (30\%) であった。部分発作から全身痤 攣へ発展する例, 複数の発作型の合併例は Table 1 に示すごとくである。 単純部分発作14例のうち感覚症状を示すものは
6 例であり，これらは全例視覚症状であった。閃 輝の感覚は 6 例全例に認められたが，その色彩・ 形・光の移動の有無などは症例によって異なり, また同一症例でもその時々の発作によって変化す る傾向があった。また，目が見えなくなるとか視 野の欠損・狭窄といった症例が 4 例に見られた が，これらは全例閃輝を伴っていた。さらに，物 が変形してみえる(2 例),小さくみえる(micropsia 1 例) といった錯視症状を示す例もあった。な 
Table 1 Type of seizure (27 cases)

\begin{tabular}{ll}
\hline Simple partial seizure & $\mathbf{1 4}$ \\
sensory (visual) & 4 (evolving to g.c. 2) \\
motor & 7 (evolving to g.c. 4 ) \\
sensory +motor & 2 \\
motor + g.c. & 1 \\
complex partial seizure & $\mathbf{5}$ \\
c.p.s. only & 3 (evolving to g.c. 2) \\
c.p.s. +g.c. & 2 \\
generalized convulsion & $\mathbf{8}$ \\
\hline
\end{tabular}

c.p.s.: complex partial seizure

g.c.: generalized convulsion

抒，視覚症状を示す例は，全例 7 歳以後の発症で あった。

また，発作時（とくに発作開始時）自律神経症 状（めまい，頭痛，腹痛など）を示したものが 9 例 (33\%) あったが，このらち視覚症状に頭痛を 伴う偏頭痛様症状は 2 例に認められたのみであ る。

焦点運動発作は 9 例（33\%）にみられたが，そ の内容は眼球偏位 ( 6 例), 一側顔面痤攣 ( 3 例), 回転発作 (versive seizure 5 例), 一側上肢ないし 下肢の瘥攣 ( 3 例), 眼振様発作 (oculoclonic seizure 1 例) であった。な执，これら運動症状を2 つ以上重複して示す例もあった。

発作出現時間は，覚醒時のみのもの 17 例（63 $\%)$, 睡眠時のみのもの 5 例 (19\%), 覚醒・睡眠 時いずれも発作を生じるもの 5 例 (19\%) であっ た。

\section{3. 脳波所見の特徵}

後頭部発作波は，ほとんどの例でてんかん発作 発症後に見出されたものであるが，1例の久軽度 の頭部打撲後の脳波検査で後頭部発作波を指摘さ れ (5 歳 6 力月時), 経過観察中 1 年 8 力月後に てんかん発作を生じた例があった。

発作波初回出現時の laterality るると, 一側 出現は15例 $(56 \%$, 左 9 例, 右 6 例), 両側独立 出現 2 例 $(7 \%, 2$ 例とも左側に高頻度), 両側 同期出現 10 例 (37\%, 振幅の差をみると, 左優位 4 例，右優位 4 例，両側対称性 2 例）であった。 両側同期出現例では, その後優位側が变化したも のが 3 例（いずれも右優位から左優位へ）あった
が，一側出現例で左右の出現側変化を みたものはなかった。また，一側出現 から両側同期出現へ，あるいは，その 逆の変化を示した例もなかった。

次に，睡眠叔よび開閉眼に対する発 作波の反応性をみた。まず，覚醒時と 睡眠時（stage 1 牡よび 2) に打ける 発作波の出現頻度を比較した。覚醒時 よりも睡眠時に発作が増加するものが 17例 $(63 \%)$ と多く,このなかには睡 眠時のみに発作波が出現する 6 例が含 まれている。逆に，覚醒時に比べ，睡 眠時に発作波が減少するものが 7 例 (26\%) あ り, 覚醒・睡眠時とも出現頻度が变化しないもの が 3 例 $(11 \%)$ であった。開閉眼への反応では, 覚醒時に発作波を認めた21例のうち8例（38\%） で閉眼による増強，開眼による抑制といったパタ ーンがみられた。しかし，他の13例では開閉眼の 影響は認められなかった。開閉眼に対する上記の 抑制・増強の反応は，発作波が頻回に出現する例 ほど顕著にみられる傾向があり，波形による差は なかった。な括, 治療初期に光過敏性 (photoconvulsive response) を示した例が 2 例あり，このう ち 1 例は過呼吸でも後頭部発作波が増強された。 過呼吸による賦活効果をみたのはこの 1 例のみで ある。

\section{4. 脳波所見と臨床症状との関連}

後頭部発作波が睡眠時に減少するもの（7 例） は全例が覚醒時のみの発作を示し, 発作時視覚症 状を認めるものが多かった（7 例中 5 例)。逆に, 睡眠により発作波が増加する例では視覚症状が少 なかった（17例中 1 例)。また，発作波が開閉眼 の影響をらける例は，覚醒時のみに発作を和こす ものが多かった（8例中 7 例）が，視覚症状との 関連は認められなかった。な挔, Gastaut ${ }^{5)}$ が BEOSW に特徵的な脳波パターンとした後頭部反 復律動性棘徐波複合は，著者らの対象では 5 例に 認められたが，そのらち視覚症状拉よび頭痛とい った発作症状を示したのは 2 例のみであった。

\section{5. 既往歴および家族歴}

器質性脳障害を残したと考えられる既往歴は7 例 $(26 \%)$ に認められ，その内訳は，出産時仮死 


Age $\begin{array}{rrrrrrrr}0 & 5 & 10 & 15 & 20 & 25 & 30 & 35 \\ \text { yrs. }\end{array}$

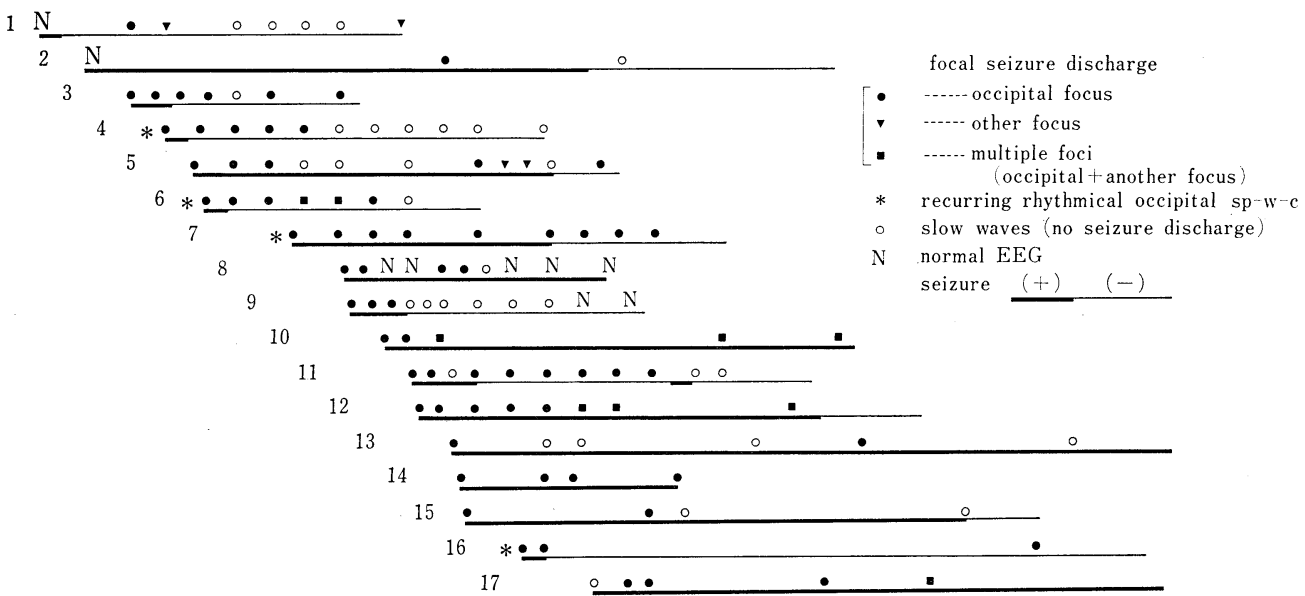

Fig. 4 The course of clinical seizure and EEG findings

3 例 (らち 1 例は脳性麻㽻), 脳炎 2 例, 30 分以 上の意識障害を伴う 頭部外傷 2 例であった。ま た，4例に熱性痤攣の既往があった。さらに，知 能障害が 5 例に, 眼科的異常が 3 例（先天性白内 障, 弱視, 内斜視, 各 1 例）にみられた。な和, CT スキャンは 6 例に施行されたが，異常が認め られたのは 1 例（水頭症）のみであった。

一方, 痤攣性疾患の家族歴を 4 親等の範囲でと りあげたところ，15例（56\%）に認められ，その 内訳は，てんかん 5 例, 熱性痤攣 5 例, 乳幼児期 の病攣 4 例，てんかん十熱性痤攣 1 例であった。 な和，後頭部反復律動性棘徐波複合を示す 5 例の らち 4 例がてんかんまたは熱性㾏攣の家族歴を有 していた。偏頭痛の家族歴については，情報不十 分のため今回は検討しなかった。

\section{5. 臨床・脳波学的経過 (Fig. 4)}

今回の対象のうち 5 年以上にわたり発作および 脳波所見を追跡できたのは17例であった。経過観 察期間は 6 年 2 力月から 21 年 5 カ月まで（平均 11 年 9 カ月）である。経過の判定は，今回の検討の 時点で最終発作以降 3 年以上を経過し, 発作の再 発をみていないものを予後良好とし，それ以外の ものを予後不良とした。その結果，予後良好は 8 例 $(47 \%)$ ，予後不良は 9 例 $(53 \%)$ であった。 予後良好群に抢ける発作消失の時期は，症例によ りばらつきが大きく，年齢との間に一定の関係は
見出せなかった。臨床所見と予後との関連につい てみると, 器質性脳障害や知能障害を有する例, 複雑部分発作を示す例, 発症年齢の高い例では予 後不良の傾向があった。一方，てんかんの家族歴 や視覚症状の有無と発作の予後との間に明らかな 関連は認められなかった。

脳波所見の経過をみると，発作波の消失時期 は，臨床発作のそれと同様個人差が大きく，一定 の傾向はなかった。年齢が高くなるにつれて，発 作波は鋭さを減じ，棘波から鋭波へと変化してい く傾向があるが，20歳以降も出現し続ける例も少 なくない（5 例)。経過中，発作波が後頭部のみ に見られたのは11例（65\%）であるが，他の 6 例 (35\%) では焦点部位の変化を認めた。すなわち, 2 例は後頭部以外の部位に発作波を認めるように なり（中側頭部，中心一頭頂部，各 1 例), 4 例は 後頭部を含も多焦点性発作波に变化した（後頭部 以外の焦点部位は, 前側頭部 2 例, 中心部 1 例, 中側頭部を経て前側頭部へと変化したもの 1 例)。 脳波的特徵と予後との関連をみると，睡眠や開 閉眼に対する発作波の反応性と予後との関連は見 出せなかった。光過敏性を示した例は 2 例とも予 後不良群に含まれた。また, 発作波焦点が変化し たもの（多焦点例も含む）についてみると，前側 頭部に焦点を認めるようになった例では予後が悪 く，中心部または中側頭部へ変化した例では必ず 
しも悪くないという結果であった。な扬，後頭部 反復律動性棘徐波を呈する例のうち，5年以上経 過を追えた 4 例は全例が15歳までに臨床発作の消 失をみた。また，経過中，1例は中心部にも焦点 を有する多焦点発作波の形をとった。20歳以降ま で追跡しえたのは 1 例のみであるが，この例は14 歳の発症であり，29歳時の脳波でも後頭部鋭波が 認められた。

\section{III. 考察}

後頭部発作波の出現年齢に関して, Gibbs らは, 大部分の症例では10歳以前に出現し, そのピーク は 4 歳7または 5 〜歳8)であると述べている。一 方, Ludwig ら ${ }^{10)}$ は 1 歳から61歳までの範囲に分 布している (中央值17歳) と報告している。後頭 部発作波といっても, その出現様式や分布のしか たによって出現しやすい年齢に多少のちがいがあ ることは Ludwig ら $^{10}$ そより指摘されて和り,さ らに対象母集団の年齢構成の差も上記の報告者の 結果に影響を与えているものと推測される。著者 らは, 初診時年齢掠よび発作波が初めて検出され た年齢を検討した。との結果，後頭部発作波は 4 歳から15歳までの間に出現しやすいが，とくに8 〜11歳で高率に認められるものと考えられた。

一方, 後頭部発作波を示すてんかんの初発年齢 についても報告者により差異がみられる。Gibbs $5^{6)}$ は, 小児期早期に発症するものが多く, 症例 の $21 \%$ 歳以前の初発であったとしている。ま た, Gastaut ${ }^{5)}$ は, 後頭部反復律動性棘徐波の症 例について, 発作初発が平均 6 歳であったと述 ベ, Beaumanoir ${ }^{2}$ も同様の症例に和いて, ピーク が 4 〜 歳であったと報告している。しかし，

Ludwig $5^{10)}$ は発作初発年齢が生後 5 週から61歳 までの広い範囲に分布し，症例の $95 \%$ は 8 歳以後 の発症であったと述べている。著者らの場合, 発 作波の年齢分布と一致して $4 \sim 11$ 歳に発症する例 のほかに, 3 歳以前に発症する例も少なくないと いう結果であった。

後頭葉発作発射に由来する臨床発作症状に関し ては，すでに脳の電気刺激， Metrazole などによ る賦活拉よび深部電極記録により詳細な検討が行 われている1,12,14)。それによると，視覚症状のみ
ならず，それにひき続いて種々の焦点性運動・感 覚症状掞よび自動症, 全身痙攣など多様な症状が みられることが知られて拉り，これらの症状は， 後頭葉から他の部位への発作活動の伝播によるも のと考光られている。

一方，発作間歇時脳波で後頭部限局性発作波を 示すてんかんの臨床発作像に関してもいくつかの 報告があるが，この場合，上記のような監視下での 記録と異なり, 症状の見落しがあることや，発作 発現様式がちがうことが考慮される必要がある。 視覚症状の出現について Gibbs ら ${ }^{6)} 9 \%$, Smith

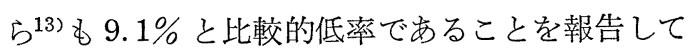

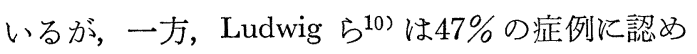
られたと述べている。しかし，既に述べたよら に, 前 2 者の対象は若年小児であり, 後者のそれ は年長者であることから，表現能力も含めた年齢 要因が関与していることは否定できない。因み に, 著者らの場合, 両者の中間の年齢層が対象と なっているが，そのうち視覚症状は $22 \%$ に認めら れた。また, 視覚症状を認めたのはいずれも 7 歳 以後に発症した症例であった。

運動症状については, Gibbs $5^{6)}$ は全般性強直 間代発作が最も多いと記載しており, Smith ら ${ }^{13)}$ も, 全般性強直間代発作が最も多く $(39.8 \%)$, ついで焦点発作 $(34.3 \%)$, 二次性全般化発作 (13.8\%) の順であったと述べている。また， Ludwig $ら^{10)}$ は55例中44\%は全般性強直間代発作 または強直発作であったが，49\%は焦点運動症状 を示し，運動症状を認めなかったのは $9 \%$ たすぎ ないと述べている。焦点運動症状として, Smith ら ${ }^{13)}$ は頭部あるいは眼球の偏位回転が $24.2 \%$ 見 られたとし, Ludwig ら $5^{10)}$ も同様の回転症状が 29 \%に見られ，発作性の眼振は $9 \%$ のス見られた と報告している。著者らの検討では, 焦点運動症 状は $33 \%$ に認められたが, 眼振様発作が見られた のは 1 例のみであった。な拉，深部電極を用いた 後頭葉起源の発作記録では, 眼球や頭部の強直性 偏位, 眼振様運動 (oculo-clonic movements), 眼 瞼の痤攣などが発作の初期症状として指摘されて いる14)。

ところで, 後頭部発作波を示す症例が複雑部分 発作と密接な関連を有することもよく知られてい 
$ろ^{5,9,10)}$ 。Ludwig $5^{10)}$ は，後頭部発作波を示すて んかん患者で自動症が多くみられた（29\%）と報 告し，視覚症状が先行する点を除けば典型的な側 頭葉起源の自動症と区別でさないと記載してい る。そして，これは発作活動の側頭葉深部への波 及によるものと考它られている5,10)。著者らの場 合，自動症が認められたのは 2 例のみであった が，両者とも，その後脳波の上で前側頭部焦点を 示すようになったことは上記の見解を側面から支 持するものと考光られる。な特，発作時の自律神 経症状は，著者らの例では $33 \%$ に認められた。 Smith $5^{13)}$ も21\%の例で自律神経症状の発作性工 ピソードがみられたとしている。 Ludwig ら ${ }^{10)}$ は 上腹部症状やめまい感の出現を後頭部から前方へ の発作発射の拡大として解釈している。偏頭痛症 状との関連も以前から指摘されているところであ るが，この点については後述する。

最後に, 後頭部発作波を示すてんかんの予後に ついて考察してみたい。Gibbs ら ぎると症例の $40 \%$ は脳波が正常化し，てんかん 発作も消失すると述べている。しかし，福島は4) 小児から成人までを含むてんかん症例で発作波の 焦点部位別に予後を検討した結果, 中心部一中側 頭部焦点例の予後が良好なのに対し, 後頭部焦点 例の予後が不良であると報告している。また， Ludwig $5^{10)}$ も，8歳以後発症例について，10年 間以上あるいは20歳すぎまで追跡したが，症例の 95\%は臨床的にも脳波的にも改善がみられなかっ たとし，Gibbs らの主張する予後良好な小児後頭 葉てんかんの頻度は実際は少ないと述べている。 このことは，後頭部発作波を示すてんかんの予後 を左右する因子の 1 つは年齢であり, 若年発症例 では比較的良好な経過をとる可能性を示唆してい る。著者らの例でもその傾向が指摘された。ま た, 器質性脳障害や知能障害, 複雑部分発作の存 在も予後不良と結びつく因子と考兄られた。脳波 的には, 前側頭部焦点の出現や光過敏性が予後を 悪くする可能性として示唆された。

ところで，すでに述べたように，Gastaut ${ }^{5)}$ は BECCT に匹敵する予後良好な小児てんかんの新 しいタイプとして BEOSW の概念を提唱した。 すなわち，脳波では閉眼で増強し，開眼で抑制さ
れる後頭部反復律動性棘徐波複合を示し, 臨床像 として発作開始時の視覚症状と発作後の頭痛を特 徵とすること，19歳までに $92 \%$ 症例で発作抑制 が得られたことを指摘した。また，てんかんの家 族歴が高率であることや，経過中に Rolandic spikes や全般性両側同期性棘徐波複合を示す例の あることから，BECCT と同様の functional focus を有するてんかんとして位置つけている。このよ らな予後良好な一群があることは，すでに Camfield $ら^{3)}$ が報告しているが，彼らは偏頭痛症状を 重視し，てんかん発作や発作波の出現は偏頭痛 (basilar migraine) の反復によって生じた脳底動 脈領域の虚血性変化に由来するとの見解を示し た。これに対し, Gastaut ${ }^{5)}$ はあくまでもてんかん を基本病態としてとらえ, 偏頭痛症状は後頭葉発 作発射の上部脳幹への伝播として説明可能である と述べている。その後, Beaumanoir ${ }^{2)}$ は同様の脳 波所見を示す予後良好な小児てんかんについて報 告し，発作が睡眠中に多い，部分発作で発作後の 障害を残さない，全般発作で発症するものが多 い，神経学的異常がない，てんかんの家族歴が高 率であるなどの点を BECCT との類似点として 強調している。しかし，睡眠が発作波を増強す る, 発作後の頭痛は少ない, 眼科的異常が多いと いった点は上記の BEOSW の特徵と異なる。と ころで, 最近, Newton ら ${ }^{11)}$ は, やはり同様の脳 波所見を示すてんかん小児について報告している が，Gastaut の主張する予後良好なてんかんの一 型としてのとらえ方に批判を加えている。すなわ ち, 発作は一過性の意識消失を主体とする多様な 症状を示し, 偏頭痛や視覚症状が必ずしも特徵的 ではないこと，てんかんや偏頭痛の家族歴も少な く, 器質性脳病変を有する例もあり病因も一様で はないこと，発作の予後も BECCT ほど良いとは いえないことを指摘している。このように, 脳波パ ターンをある特定のものに限定しても, その臨床 像，脳波的特徵拉よび経過の面ではかなり異質な ものが入ってくることが示唆されるわけである。

そこで，著者らの例をみると，この脳波パター ンを示した例は少数で，経過観察期間も十分では ないが，扣扣よそ次のよらな結果が得られた。発 作は治療開始後，比較的早期に抑制される傾向が 
あった。また, 痤攣性疾患の家族歴を有する例が 多かった。しかし，特異的な発作症状があるとは 考えにくい。開閉眼に対する発作波の反応は，こ のパターンに特有な現象ではなく, 発作波の出現 頻度と関連するものと考兄られた。中心部または 中側頭部領域の発作波焦点は, このパターン以外 の症例でも認められた。20歳以降も発作波を示す 例があったが，この例は発症年齢が高かった。発 症が招そい場合，予後が良くない傾向があること は前述の通りなので, この例の場合, 治療の効果 といらことも考慮する必要があろう。以上の結果 から, 後頭部反復律動性棘徐波複合は予後良好を 示唆する可能性はあっても, 臨床・脳波的一単位 の指標としてはとらえがたいものと考えられる。

\section{文献}

1) Ajmone Marsan C, Ralston BL. The Epileptic Seizure, Its Functional Morphology and Diagnostic Significance. Springfield: Charles C Thomas, 1957; 211-215.

2) Beaumanoir A. Infantie epilepsy with occipital focus and good prognosis. Eur Neurol 1983; 22: 43-52.

3) Camfield PR, Metrakos K, Andermann F. Basilar migraine, seizures, and severe epileptiform EEG abnormalities. A relatively benign syndrome in adolescents. Neurology 1978; 28: 584-588.

4）福島 裕：てんかんの予後と脳波一限局性棘波異 常を中心に一. 臨床脳波 1969; 11：287-290.

5) Gastaut H. A new type of epilepsy: Benign partial epilepsy of childhood with occipital spikewaves. Clin Electroencephalogr 1982; 13: 13-
22.

6) Gibbs FA, Gibbs EL. Atlas of Electroencephalography. Vol. 2. Mass: Addison-Wesley, 1952; 222-224.

7) Gibbs EL, Gillen HW, Gibbs FA. Disappearance and migration of epileptic foci in childhood. Amer J Dis Child 1954; 88: 596-603.

8) Gibbs FA, Gibbs EL, Gibbs EL, Gibbs, TJ. Relation between specific types of occipital dysrhythmia and visual defects. Johns Hopkins Med J 1968; 122: 343-349.

9) Houtt AD, Madison DS, Niedermeyer E. Occipital lobe epilepsy. A clinical and electroencephalographic study. Europ Neurol 1974; 11: 325-339.

10) Ludwig BI, Ajmone Marsan C. Clinical ictal patterns in epileptic patients with occipital electroencephalographic foci. Neurology 1975; 25: 463-471.

11) Newton R, Aicardi J. Clinical findings in children with occipital spike-wave complexes suppressed by eye-opening. Neurology 1983; 33: 1526-1529.

12) Penfield W, Jasper H. Epilepsy and the Functional Anatomy of the Human Brain. Boston: Little Brown, 1954; 401-406.

13) Smith JMB, Kellaway P. The natural history and clinical correlates of occipital foci in children. In: Kellaway P, Petersen I, ed. Neurological and Electroencephalographic Correlative Studies in Infancy. New York: Grune \& Stratton, 1963; 230-249.

14) Takeda A, Bancaud J, Talairach J, Bonis A, Bordas-Ferrer M. Concerning epileptic attacks of occipital origin. Electroenceph clin Neurophysiol 1970; 28: 647-648.

\section{Summary}

\section{Clinico-electroencephalographical Study of Epilepsy with Occipital Seizure Discharges}

Fumio Saito, Yutaka Fukushima, Shuji Kubota, Tokijiro Sato

Clinical features and outcome of 27 epileptic patients with occipital EEG foci were investigated. The age at the first examination distributed between 4 months and 17 years, with a peak between 8 and 11 years. Family history of convulsive disorders was found in 15 patients (56\%). The seizure types and number of the cases were as follows; simple partial seizures $14(52 \%)$, complex partial seizures $5(19 \%)$ and generalized convulsions $8(30 \%)$. In 6 patients of the cases with partial seizures, the seizures 
began with visual symptoms. Migrainous symptoms were present in 2 cases. As to EEG findings, in 17 cases, the occipital seizure discharges were increased in sleep recording. Visual stimulus suppressed the discharges in 8 cases.

In clinical and EEG follow-up of 17 cases, it was found that 8 cases (47\%) had been free from seizure for at least 3 years at the time of the study, and the occiptal seizure discharges persisted over 20 years of the age in 5 cases. During the follow-up period, 2 cases showed a change in the site of focus, and 4 cases produced new focus in another area, in addition to occipital areas.

Among the subjects, 5 cases exhibited recurring rhythmic occipital spike wave complexes, proposed as benign partial epilepsy of children with occipital spike-waves (BEOSW) by Gastaut (1982). The clinical course of these cases showed relatively favorable outcome. However, in one patient the occipital spikes were still observed in the EEG at the age of 29 years. There was no evidence confirming the relationship between this characteristic EEG pattern and specific ictal manifestations. It seemed to be difficult, therefore, to consider the cases as a benign electro-clinical entity.

In conclusion, epileptic patients with occipital foci showed wide range of clinical features and the prognosis was not always good. The outcome appeared to be depend on the age at seizure onset, and also on seizure type, organic brain damage and mental retardation.

J. Jpn. Epil. Soc. $1985 ; 3: 108-116$ 